\title{
$\square$
}

\section{Are the Causes of Bank Distress Changing? Can Researchers Keep Up?}

\author{
Thomas B. King, Daniel A. Nuxoll, and Timothy J. Yeager
}

\begin{abstract}
Since 1990, the banking sector has experienced enormous legislative, technological, and financial changes, yet research into the causes of bank distress has slowed. One consequence is that traditional supervisory surveillance models may not capture important risks inherent in the current banking environment. After reviewing the history of these models, the authors provide empirical evidence that the characteristics of failing banks have changed in the past ten years and argue that the time is right for new research that employs new empirical techniques. In particular, dynamic models that use forward-looking variables and address various types of bank risk individually are promising lines of inquiry. Supervisory agencies have begun to move in these directions, and the authors describe several examples of this new generation of early-warning models that are not yet widely known among academic banking economists.
\end{abstract}

Federal Reserve Bank of St. Louis Review, January/February 2006, 88(1), pp. 57-80.

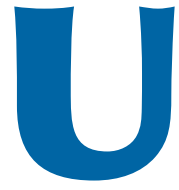

nderstanding the causes of insolvency at financial institutions is important for both academic and regulatory reasons, and the effort to model bank deterioration was once a vibrant area of study in empirical finance. Significant advances were made between the late 1960s and late 1980s. Since then, research has slowed considerably on the characteristics of banks headed for trouble, reflecting a sense among researchers that the causes of banking problems are unchanging and well understood. In this article, we argue that this complacency may be unwarranted. ${ }^{1}$ The rapid pace of technological and institutional change in the banking sector in recent years suggests that the dominant models may no longer accurately

1 Note that we are not claiming that bank regulators have grown complacent, only that the academic community has focused its attention away from this issue. represent the nature of bank deterioration. Indeed, the few observations that we have of recent bank failures provide evidence consistent with this hypothesis.

The changes in the banking environment call for renewed research into the causes of bank distress. The federal supervisory agencies have established research programs pursuing this goal, but-because regulatory banking economists often work on projects with confidential data and because many ongoing projects are not formally disclosed to the public -it can be difficult for outside economists to benefit from this work. By describing some efforts that are currently underway to develop new early-warning models at the Federal Reserve and Federal Deposit Insurance Corporation (FDIC), we attempt to bridge that gap in the hope of stimulating more research in this area beyond that done by government agencies. One strand of the new monitoring devices attempts

Thomas B. King is an economist at the Federal Reserve Bank of St. Louis; Daniel A. Nuxoll is an economist at the Division of Insurance and Research, Federal Deposit Insurance Corporation; and Timothy J. Yeager is the Arkansas Bankers' Association Chair of Banking at the University of Arkansas. (Yeager was an assistant vice president and economist at the Federal Reserve Bank of St. Louis at the time this article was written.) The authors thank Alton Gilbert, Hui Guo, Andy Meyer, Greg Sierra, and David Wheelock for helpful comments. The views expressed are those of the authors and are not necessarily official positions of the Federal Reserve Bank of St. Louis, the Board of Governors of the Federal Reserve System, or the FDIC.

(C) 2006, The Federal Reserve Bank of St. Louis. Articles may be reprinted, reproduced, published, distributed, displayed, and transmitted in their entirety if copyright notice, author name(s), and full citation are included. Abstracts, synopses, and other derivative works may be made only with prior written permission of the Federal Reserve Bank of St. Louis. 
to complement traditional early-warning models by adopting a more theoretical approach using forward-looking variables. Another strand isolates and models unique banking risks to facilitate the risk-focused approach to bank supervision. A common objective of these models is an increased flexibility that will allow off-site surveillance to better keep pace with the dynamic banking environment going forward.

\section{SURVEILLANCE MODELS IN HISTORICAL CONTEXT}

Federal bank supervisors primarily use limiteddependent-variable regression models for off-site monitoring. Although we argue later that these models (like all models) have shortcomings, they reflect years of advancement in academic research, econometric modeling, and computer technology. In this section, we describe the evolution of offsite surveillance models, paying particular attention to the link between academic research and supervisory applications. Table 1 summarizes the evolution of various off-site surveillance systems at the Federal supervisory agencies from the mid1970 s to the present. The systems transitioned from simple screens, to hybrid models, to the econometric models used today.

\section{Discriminant Analysis and Supervisory Screens}

During the 1960s, several studies attempted to determine the usefulness of various financial ratios in predicting bankruptcy in non-bank firms. In his seminal article, Altman (1968) used discriminant analysis over five variables to determine the characteristics of manufacturing firms headed for bankruptcy. His paper ushered in a wave of research applying similar methodology specifically to depository institutions, including Stuhr and van Wicklen (1974), Sinkey $(1975,1978)$, Altman (1977), and Rose and Scott (1978).

Much of this early research on bank distress was conducted by economists within supervisory agencies, and some of it was specifically directed toward the establishment of an off-site earlywarning model for use in everyday supervision.
Because discrete-response-regression techniques were still relatively new and too computationally intensive to be practical, the initial screen-based systems adopted by all three federal agencies relied on a variant of discriminant analysis, comparing selected ratios to predetermined cutoff points and classifying banks accordingly.

The Office of the Comptroller of the Currency (OCC) adopted the first formal screen-based system called the National Bank Surveillance System (NBSS) in 1975. Previously, off-site monitoring had consisted largely of informal rules of thumb based on individual financial ratios. According to White (1992), the impetus for the shift toward a more systematic approach was the OCC's failure to detect the financial difficulties at two large institutions-United States National Bank and Franklin National Bank - that became insolvent in the early 1970s. The OCC's response to these shortcomings in off-site surveillance was, in part, to avail itself of new computing technology to condense the call-report data into key financial ratios for each bank under its supervision. One component of the NBSS, the Anomaly Severity Ranking System, ranked selected bank ratios within peer groups to detect outliers.

The FDIC and the Federal Reserve quickly followed the OCC with similar screen-based models of their own. In 1977, the FDIC introduced the Integrated Monitoring System. One component of this system was the humbly titled "Just A Warning System," which consisted of 12 financial ratios. The system compared each ratio with a benchmark ratio determined by examiner judgment. Banks with ratios that "failed" various screens were flagged for additional follow-up. The Federal Reserve adopted the Minimum Bank Surveillance System (later, the Uniform Bank Surveillance Screen), which examined seven bank ratios. These ratios were weighted by their Z-scores, which were then summed to yield a composite score for each bank. MBSS, which resulted from the research program described in Korobow, Stuhr, and Martin (1977), was the first surveillance model adopted by a supervisory body to employ formal statistical techniques. 


\section{Discrete-Response Models and Hybrid Systems}

The development of discrete-response regression techniques, together with the increased availability of the computing power necessary to apply them to large datasets, aided the advancement of bank-distress models beginning in the late 1970s (Hanweck, 1977, Korobow, Stuhr, and Martin, 1977, and Martin, 1977). Because of its analytical simplicity, the logistic specification has been the favorite model of this type, although arctangent and probit models have also appeared occasionally. $^{2}$ As pointed out by Martin (1977), discriminant analysis can be viewed as a special case of logistic regression in that the existence of a unique linear discriminant function implies the existence of a unique logit equation, whereas the converse is not true. However, the existence of a linear discriminant function is commonly rejected when the number of observations of one class is substantially smaller than that in the other class. For this reason, early discriminant studies typically used subsamples of the population of safe banks (which have always far outnumbered risky banks by any measure), either matching them according to certain non-risk characteristics or randomly selecting the control sample. The use of a logit model obviates the need for these restrictive sampling methods.

Martin's (1977) study set the standard for discrete-response models of bank-failure prediction. Whereas most previous research had focused on a small sample of banks over two or three years, Martin used all Fed-supervised institutions during a seven-year period in the 1970s, yielding over 33,000 observations. In what would become a standard approach, he confronted the data agnostically with 25 financial ratios and ran several different specifications in search of the best fit. He found that capital ratios, liquidity measures, and profitability were the most significant determinants of failure over his sample period. Although Martin did not employ direct measures of asset quality, his indirect measures-provision expense and loan

2 Linear regression analysis was explored early on by Meyer and Pifer (1970). concentration-also turned out to be significant.

A host of other studies around the same time, using both logit and discriminant analysis, confirmed these basic results. Table 2 summarizes a selection of these papers. Poor asset quality and low capital ratios are the two characteristics of banks that have most consistently been associated with banking problems over time (Sinkey, 1978). Indeed, as described in Putnam (1983), earlywarning research in the 1970s and 1980s displayed a remarkable consistency in the variables that emerged as important predictors of banking problems: profitability, capital, asset quality, and liquidity appeared as statistically significant in almost every study, even though they were often measured using different ratios. ${ }^{3}$

Motivated in part by the consistency of the pattern of bank deterioration, the federal banking agencies adopted the Uniform Financial Rating System in November 1979. ${ }^{4}$ Under this systemwhich is still the primary rating mechanism for U.S. bank supervision—capital adequacy (C), asset quality (A), management competence (M), earnings performance (E), and liquidity risk (L) are each explicitly evaluated by examiners and rated on a 1 (best) to 5 (worst) scale. (Beginning in 1997, sensitivity to market risk (S) was adopted as a sixth component.) Examiners also assign a composite rating (CAMELS) on the same scale, reflecting the overall safety and soundness of the institution.

From a supervisory perspective, modeling CAMELS ratings allows examiners to observe estimates of current supervisory ratings on a quarterly basis, rather than only during an on-site exam. The availability of consistent supervisoryrating data beginning in 1979 allowed researchers to employ ordered logit techniques to estimate bank ratings. (See West, 1985; and Whalen and

\footnotetext{
3 More recently, some research has investigated the potential for local and regional economic data to add information about future banking conditions. However, the results have largely rejected this idea (e.g., Meyer and Yeager, 2001; Nuxoll, O'Keefe, and Samolyk, 2003; and Yeager, 2004). On the other hand, Neely and Wheelock (1997) show that bank earnings are highly correlated with statelevel personal-income growth.

4 Prior to 1979, the three federal regulatory agencies assigned banks scores for capital (1 to 4), asset quality (A to D), and management (S, F, or P), as well as a composite score (1 to 4).
} 


\section{Table 1}

\section{Evolution of Key Off-Site Surveillance Systems}

\begin{tabular}{lcc} 
Screen-Based Systems & Agency & Period used \\
\hline National Bank Surveillance System (NBSS) & OCC & 1975 to ? \\
Condensed the call-report data into key financial ratios and compared them to peer ratios. One output of the NBSS, \\
the Anomaly Severity Ranking System, ranked bank ratios by peer group to detect outliers. Another output was the \\
Bank Performance Report. In cooperation with the Fed and FDIC, the OCC transformed the Bank Performance Report \\
into the Uniform Bank Performance Report (UBPR). Although the OCC no longer uses the NBSS, the UBPR is used \\
presently by all federal and state supervisory agencies for both on-site and off-site analysis.
\end{tabular}

\section{Minimum Bank Surveillance Screen (MBSS) \\ Federal Reserve \\ Late 1970s to mid-80s}

Employed a set of ratios as off-site screens and added institutions that lay outside a critical range to an "exception list" that received extra scrutiny. A composite score was also constructed by summing the normalized values of seven of these ratios.

\section{Integrated Monitoring System (IMS) \\ FDIC \\ 1977 to 1985}

A screening device within the IMS, called the "Just A Warning System" (JAWS), compared 12 key financial ratios to critical values as determined by examiner expertise. JAWS did not compute composite scores or make direct comparisons to peer levels.

Uniform Bank Surveillance Screen (UBSS)

Federal Reserve

Mid-1980s to 1993

Improvement upon the MBSS. Computed peer-group percentiles of six financial ratios and summed them to derive the composite score. Banks in the highest percentiles of the composite score were placed on a watch list.

Hybrid Systems

\section{CAEL}

Agency

FDIC
Period used

1985 to late 1998

Replaced IMS. An "expert system," designed to replicate the financial analysis that an examiner would perform to assign an examination rating. Ratios were chosen to evaluate capital (C), asset quality (A), earnings (E), and liquidity (L). Analysts subjectively determined the weights for each of the ratios that fed into the four CAEL components. The CAEL components were multiplied by their respective weights and summed to yield a composite CAEL score.

\section{Canary}

OCC

2000 to present

Canary consists of a package of tools organized into four components: Benchmarks, Credit Scope, Market Barometers, and Predictive Models. Benchmarks are screen-based ratios that indicate risky thresholds. The Peer Group Risk Model is a predictive model that projects a bank's return on assets over the next three years under various economic scenarios. 


\title{
Table 1, cont'd
}

\begin{abstract}
Limited-Dependent Variable Systems
Agency

Period used

System to Estimate Examination Ratings (SEER)

Federal Reserve

1993 to present

Replaced the UBSS. First named the Financial Institutions Monitoring System, SEER is a logit model that consists of two components, a "risk-rank" model that forecasts bank-failure probabilities and a "rating" model that estimates current CAMELS scores.

Statistical CAMELS Off-site Rating (SCOR)

FDIC

1998 to present

Replaced CAEL. Like SEER, the model consists of two components: a CAMELS downgrade forecast and a rating forecast. The downgrade forecast computes the probability that a 1- or 2-rated bank will receive a 3, 4, or 5 rating at the next examination. The OCC also uses output from the SCOR model in off-site surveillance.
\end{abstract}

CAMELS Downgrade Probability (CDP)

Federal Reserve Bank of St. Louis

1999 to present

Similar to the downgrade forecast of SCOR, the CDP estimates the probability that a 1- or 2-rated bank will be downgraded to a 3 , 4 , or 5 rating over the next two years.

\begin{tabular}{lcc} 
Forward-Looking Early-Warning Systems & Agency & Period used \\
\hline Growth Monitoring Sytem (GMS) & FDIC & 2000 to present
\end{tabular}

Although GMS was initially developed as an expert system and implemented in the 1980s, it was revised significantly in the late 1990s to employ explicit statistical techniques. GMS is a logit model of downgrades that estimates which institutions that are currently rated satisfactory are most likely to be classified as problem banks at the end of three years. Rather than using credit quality measures as independent variables, GMS includes forward-looking variables such as loan growth and noncore funding that can be precursors of problems that have yet to manifest themselves.

\section{Liquidity and Asset Growth Screen (LAGS) \\ Federal Reserve Bank of St. Louis \\ 2002 to present}

LAGS is conceptually similar to GMS, but it uses a dynamic vector autoregression approach to forecast the set of banks most likely to exploit moral hazard-incentives. Such banks exhibit rapid loan growth, increasing dependence on funding sources with no market discipline, and declining capital ratios. Like GMS, the model uses forward-looking variables.

\begin{tabular}{lcc} 
Risk-Focused Systems & Agency & Period used \\
\hline Real Estate Stress Test (REST) & FDIC & 2000 to present
\end{tabular}

REST attempts to identify those banks and thrifts that are most vulnerable to problems in real estate markets by subjecting them to the same stress as the New England real estate crisis of the early 1990s. Forecast measures of bank performance are translated to CAMELS ratings using the SCOR model. The result is a REST rating that ranges from 1 to 5 .

Economic Value Model (EVM)

Federal Reserve

1998 to present

The EVM is a duration-based economic value of equity model that estimates the loss in a bank's market value of equity given an instantaneous 200-basis-point interest rate increase. The model is useful to assess the bank's long-run sensitivity to interest rate risk. 


\section{Table 2}

\section{Comparison of Selected Early Studies Predicting Bank Condition}

\begin{tabular}{|c|c|c|c|c|c|c|c|c|}
\hline Model number & (1) & (2) & (3) & (4) & (5) & (6) & (7) & (8) \\
\hline Dependent variable & Failure & Rating & Failure & Failure & Failure & Rating & Failure & Rating \\
\hline Technique & OLS & $\begin{array}{l}\text { Discriminant } \\
\text { analysis }\end{array}$ & Logit & Probit & Probit & Factor + Logit & Logit & Factor + Logit \\
\hline No. of observations & 60 & 214 & 33,627 & 221 & 820 & $\sim 5,700$ & 339 & 70 \\
\hline Sample period & $1948-65$ & $1967-68$ & $1969-76$ & $1971-76$ & $1980-83$ & 1980-82 & 1983-84 & $1983-86$ \\
\hline Loans vs. securities mix & & $x$ & $x$ & $x$ & $x$ & $x$ & $x$ & \\
\hline $\begin{array}{l}\text { Efficiency, net operating } \\
\text { expense, or overhead }\end{array}$ & $x$ & $x$ & $x$ & $x$ & $x$ & $x$ & & $x$ \\
\hline ROA or ROE & $x$ & $x$ & $x$ & & & $x$ & $x$ & $x$ \\
\hline Capital/assets & & $x$ & $x$ & $x$ & & $x$ & $x$ & $x$ \\
\hline Classified loans & $x$ & $x$ & & & $x$ & $x$ & & \\
\hline Loan mix & $x$ & & $x$ & & & $x$ & $x$ & \\
\hline Size & & $\mathrm{x}$ & & $x$ & & $x$ & & \\
\hline Charge-offs & & & $x$ & & $x$ & & & \\
\hline Deposit mix & $x$ & & & & & $x$ & & \\
\hline $\begin{array}{l}\text { Past-due or nonperforming } \\
\text { loans }\end{array}$ & & & & & $x$ & & & $x$ \\
\hline Liquid assets & & & $x$ & & & $x$ & & \\
\hline $\begin{array}{l}\text { Volatile liabilities or jumbo } \\
\text { CDs }\end{array}$ & & & & & & $x$ & & $x$ \\
\hline Dividend payout ratio & & $x$ & & & & & & \\
\hline $\begin{array}{l}\text { Interest income, expense, } \\
\text { or margin }\end{array}$ & & & & & & $x$ & & \\
\hline Interest-rate sensitivity & & & & & $x$ & & & \\
\hline Provision expense & & & $x$ & & & & & $x$ \\
\hline Insider activity & $x$ & & & & & & & \\
\hline Income volatility & $x$ & & & & & & & \\
\hline Balance sheet volatility & $x$ & & & & & & & \\
\hline Asset or loan growth & $x$ & & & & & & & \\
\hline Income growth & & & & $x$ & & & & \\
\hline Loan-loss reserves & & & & & & & & $x$ \\
\hline Other & $x$ & & & & & & $x$ & $x$ \\
\hline
\end{tabular}

NOTE: Variables listed in the table are those included in each study. In most cases, variables were selected because of their significance, and so the table also largely reflects variables that were significant in predicting bank problems. In some studies, some additional variables were considered but they do not receive an " $\mathrm{X}$ " in the table because they were found to be statistically insignificant. The studies referenced are (1) Meyer and Pifer, 1970; (2) Stuhr and van Wicklen, 1974; (3) Martin, 1977; (4) Hanweck, 1977; (5) Bovenzi, Marino, and McFadden, 1983; (6) West, 1985; (7) Pantalone and Platt, 1987; and (8) Whalen and Thomson, 1988. 
Thomson, 1988. ${ }^{5}$ Cole and Gunther (1998) demonstrate that actual supervisory ratings can become obsolete within as little as six months after being assigned. Similarly, Hirtle and Lopez (1999) find that the private supervisory information contained in these ratings decays as they age. These studies suggest that early-warning models that estimate current supervisory ratings are useful tools for supervisors to keep up with bank fundamentals without incurring the cost of an examination. ${ }^{6}$

The FDIC's CAEL model, introduced in 1985, represented a significant breakthrough in off-site monitoring devices. This "hybrid" system-a discrete-response framework coupled with examiner input-estimated ratings for four of the five CAMEL components based on quarterly call-report data. ('M' was not estimated.) For each CAEL component, experienced examiners subjectively weighted the relevant bank ratios; a rating table then mapped the model output to a rating ranging from 1 to 5 . The rating table was updated each quarter to mirror the actual distribution of component CAMEL ratings in the previous year. CAEL then weighted the four estimated components themselves to yield a composite rating. In essence, the model was a calibrated limited-dependentvariable model, with examiner guidance replacing the computationally intensive econometric procedure.

\section{The Current Surveillance Regime}

A wealth of data on bank failures and CAMELS ratings throughout the 1980s and the rapid pace

\footnotetext{
5 West (1985) and Wang and Sauerhaft (1989) model supervisory ratings in a factor-analytic framework. Supervisory ratings had previously been used to measure composite risk in a discriminantanalysis study by Stuhr and van Wicklen (1974). Two other, related, lines of research begun in this period involve modeling time to failure (rather than failure probability) and regulatory closuredecision rules. Examples of the time-to-failure models, which typically involve Cox (1972) proportional-hazard specifications, can be found in Lane, Looney, and Wansley (1986), Whalen (1991), Helwege (1996), and Wheelock and Wilson (1995, 2000, 2005). For models of supervisory closure behavior, see Barth et al. (1989), Demirgüç-Kunt (1989), Thomson (1992), and Cole (1993).

${ }^{6}$ It is important to recognize that these models are intended as complements to, rather than substitutes for, on-site examination. Although CAMELS ratings do become stale rather quickly, Nuxoll, O'Keefe, and Samolyk (2003) and Wheelock and Wilson (2005) show that they still retain marginal predictive power for failures, beyond that contained in the call-report data. Thus, on-site examination appears to recover some information that is not available in bank financial statements.
}

of computer technology in the 1980s and early 1990s allowed supervisory agencies to "catch up" with the banking and econometric research and develop off-site monitoring devices employing limited-dependent-variable econometric techniques. Table 3 compares the explanatory variables used in select previous and current early-warning systems. Two systems-SEER and SCOR-are the primary surveillance tools used today by the Fed and the FDIC, respectively.

In 1993, the Federal Reserve adopted as its in-house early-warning model the Financial Institutions Monitoring System, which was modified slightly and renamed the System to Estimate Examination Ratings (SEER). This model consists of two components: a "risk-rank" or failure model that estimates bank-failure probabilities and a "rating" model that estimates current CAMELS scores. The SEER failure model is designed to detect deficiencies in balance sheet and income statement ratios that are severe enough to cause an outright failure or a critical shortfall in capital. Because these events have been rare since the inception of SEER, the variables and coefficient estimates have remained frozen since they were first estimated on late-1980s and early-1990s failures. The SEER rating model, in contrast, is reestimated on a quarterly basis, allowing for different coefficient estimates-and indeed different independent variables-in each quarter. This model has the advantage of allowing for new sources of bank risk, but it can be difficult to interpret changes in risk when the main driver of the change is the inclusion of a variable that was not present in the model in the previous quarter. The two models are used together to achieve a balance between flexibility and consistency. As Cole, Cornyn, and Gunther (1995), Cole and Gunther (1998), and Gilbert, Meyer, Vaughan (1999) demonstrate, SEER's performance is superior to a variety of other early-warning systems, including actual CAMELS scores assigned by examiners, in terms of the trade-off between its type-I and type-II error. ${ }^{7}$

\footnotetext{
7 In this case, a type-I error occurs when a bank is not predicted to fail but does. A type-II error occurs when a bank is predicted to fail but does not. For obvious reasons, regulators are more concerned with type-I errors.
} 


\section{Table 3}

\section{Comparison of Early-Warning Systems}

\begin{tabular}{lcccccccc} 
& JAWS & UBSS & CAEL & SEER & SCOR & Downgrade & GMS & LAGS \\
\hline Agency & FDIC & FRB & FDIC & FRB & FDIC & FRB & FDIC & FRB \\
Model type & Screens & Screens & Hybrid & Logit & Logit & Logit & Logit & VAR \\
Tier-1 or tangible capital & $X$ & $X$ & $X$ & $X$ & $X$ & X & & $X$ \\
Total or risk-weighted & & & & $X$ & & X & & $X$
\end{tabular}

$$
\text { assets }
$$

Past due 30

Past due 90

Nonaccruals

OREO

Residential real estate loans

C\&I loans

Securities

Jumbo CDs

Net Income (ROA)

Charge-offs

Provision expense

X

$\mathrm{X}$

X $\quad x$

Liquid assets

Loan growth

Total or risk-weighted asset growth

Volatile liability expense

Volatile liabilities

Loan-loss reserves

Loan/deposit ratio

Interest expense

Loans and long-term securities

NCNRP funding

X

X

X

X

$\mathrm{X}$

$\mathrm{X}$

$X$

Operating expenses or revenues

Change in capital

Change in deposits

Dividends

Region

Prior composite supervisory rating

Prior supervisory management rating

$X$

X

$\begin{array}{ll}X & X \\ X & X \\ X & X \\ X & X \\ & X \\ & X \\ & X \\ & X \\ X & \\ X & \\ X & \\ & \end{array}$

$x \quad x$

$x \quad x$

$\mathrm{X}$

$X$

$\mathrm{X}$

$\mathrm{X}$

$\mathrm{X}$

$\mathrm{X}$

$\mathrm{X}$

X

$\mathrm{X}$

$\mathrm{X}$

X

$\mathrm{X}$

X X

X

X

$X$

X

X

NOTE: For purposes of comparison, some liberties have been taken with variable definitions, e.g., such categories as liquid assets and tangible capital have been defined in slightly different ways in the various models and the construction of certain ratios differs slightly. 
In 1998, the FDIC developed a model similar to SEER, known as the Statistical CAMELS Offsite Rating (SCOR). The SCOR model, which replaced CAEL, also consists of two components: a rating forecast and a CAMELS-downgrade forecast. ${ }^{8}$ The rating component of the FDIC's SCOR model is similar to the SEER rating model. SCOR uses a multinomial logit model to estimate a composite CAMELS rating as well as ratings for all six of the CAMELS components, in keeping with the formulation of the preceding CAEL system. SCOR's downgrade component estimates probabilities that safe banks (those with ratings of 1 or 2 ) will receive ratings of 3,4 , or 5 at the next examination.

The Federal Reserve has recently undertaken a similar effort in modeling downgrades. Gilbert, Meyer, and Vaughan (2002) use a logistic model to estimate downgrade probabilities for CAMELS composites. The authors concluded that the variables included in SEER were also the most appropriate for their purposes; but one advantage of the CAMELS downgrade model relative to the SEER failure model is the ability to update the coefficients on a periodic basis.

In sum, researchers and practitioners have made considerable progress in developing models to predict bank distress. However, as we discuss below, these models must be complemented with newer models to account for evolution in the banking industry and nontraditional sources of bank risk.

\section{THE NEED FOR NEW WORK}

The sophistication of off-site early-warning systems since 1970 has certainly improved; but, given the dramatic changes in the banking sector over the past decade, we may expect that the current systems-like the screen-based mechanisms that preceded them-have already fallen behind the pace of financial evolution. ${ }^{9}$ The main criticism of prevailing early-warning techniques is the implicit assumption that future episodes of bank distress will look similar to past episodes

\footnotetext{
8 See Cole, Cornyn, and Gunther (1995) and Collier et al. (2003a).

9 Hooks (1995) and Helwege (1996) provide evidence on the parameter instability of traditional early-warning models over time.
}

of distress. However, significant changes in the banking environment since 1990 combined with empirical evidence that bank-distress patterns may be changing suggest that new early-warning research is needed.

\section{Recent Changes in the Banking Environment}

Shifts in the banking environment erode confidence in early-warning models because the future is less likely to reflect the past. Since 1990, banks have faced significant legislative, financial, and technological innovations.

The post-1990 legislation, summarized in Table 4, intended to impose more market discipline on banks and remove anti-competitive barriers. The Federal Deposit Insurance Corporation Improvement Act of 1991 and the National Depositor Preference Act of 1993 shifted more of the burden of bank failure from taxpayers to uninsured creditors. Several studies have documented the changes in market discipline that appear to have been caused by this legislation (Flannery and Sorescu, 1996; Cornett, Mehran, and Tehranian, 1998; Marino and Bennett, 1999; Hall et al., 2002; Goldberg and Hudgins, 2002; Flannery and Rangan, 2003; and King, 2005). In addition, legislation removed geographic branching restrictions (Riegle-Neal Act of 1994) and product restrictions (Financial Services Modernization Act of 1999). Many banks have expanded into investment banking, insurance, and other financial services, and a small but increasing fraction of bank revenue derives from fee income generated by these operations (Yeager, Yeager, and Harshman, 2005). A likely outcome of these legislative changes is a more competitive banking industry that has the ability to assume different kinds of credit risk than it assumed in the past.

In addition to the legislative changes, financial markets have widened and deepened, presenting banks with new asset and liability management opportunities and challenges. Previously illiquid assets have become more liquid as secondary markets have developed and government-sponsored enterprises such as Fannie Mae and Freddie Mac have facilitated the growth of the mortgage market. Many of these products, however, contain embed- 


\section{Table 4}

\section{Key Legislative Changes in the 1990s}

Financial Institutions Reform, Recovery, and Enforcement Act of 1989 (FIRREA)

Opened FHLB membership to commercial banks. Previously membership had been available only to thrifts and certain insurance companies. Advances from the FHLB are a ready source of non-risk-priced funding. Over twothirds of all banks are now FHLB members, and over half of them routinely utilize advances. As Stojanovic, Vaughan, and Yeager (2001) show, risky banks are more likely to rely on advances than safer banks.

\section{Federal Deposit Insurance Corporation Improvement Act of 1991 (FDICIA)}

Restricted regulatory forbearance and creditor protection through prompt corrective action and least-cost-resolution provisions. This legislation may have induced greater discipline in uninsured credit markets (see Goldberg and Hudgins, 2002 and Hall et al., 2002), resulting in higher funding costs and different liability structures for troubled institutions. Mandatory closure rules potentially increased the mean and reduced the variance of the capital levels of failing banks.

\section{National Depositor Preference (1993)}

Enacted as part of the Omnibus Budget Reconciliation Act of 1993, this legislation changed the failure-resolution hierarchy to make domestic depositors more senior claimants than foreign depositors. Like FDICIA, this legislation may have changed funding costs for risky banks and caused them to rearrange their liability structures. See Marino and Bennet (1999).

\section{Reigle-Neal Interstate Banking and Branching Efficiency Act of 1994}

Allowed bank branching across state lines. Although this Act allowed for greater geographic diversification, it also exposed banks to increased competition.

\section{The Gramm-Leach-Bliley Act of 1999 (Financial Services Modernization Act)}

Repealed the Glass-Steagal Act and allowed financial holding companies to engage in insurance, securities underwriting and brokerage services, and merchant banking. This Act introduced new potential sources of risk in banking, although it facilitated the diversification of some traditional sources of risk.

ded options that could increase exposure to interest rate risk. Liabilities have also evolved since 1990. Banks are relying increasingly on noncore funding such as brokered deposits and jumbo CDs (over $\$ 100,000$ ) as traditional checking and savings accounts and local CDs are shrinking. In addition, the Federal Home Loan Bank (FHLB) opened its doors to commercial banks in 1989, quickly becoming an important nondeposit source of funding.

(See Stojanovic, Vaughan, and Yeager, 2001;

Bennett et al., 2005; and Craig and Thomson, 2003.) These changes potentially alter both interest rate and liquidity risks. Derivatives usage at commercial banks has also exploded-the notional amount of derivatives at commercial banks increased tenfold to more than $\$ 70$ trillion between 1991 and 2003. Derivatives can be used to hedge risk, but they can also be used to speculate on market movements. ${ }^{10}$ In addition, over-the-counter derivatives potentially expose banks to counterparty risk.
Finally, as in many other industries, technological innovations revolutionized the business of banking in the 1990s. Electronic payments, online banking, and credit scoring are now common and quickly growing activities. As Claessens, Glaessner, and Klingebiel (2002) argue, these developments have the potential to change the competitive landscape dramatically. They also allow for increased operational risk, including data theft from security vulnerabilities and the facilitation of money laundering.

Overall, the new products and markets that have become available to banks in the past decade provide opportunities to diversify and hedge risk in new ways. Yet they also carry dangers-if they are not fully understood or properly managed, new business lines may end up increasing risks

\footnotetext{
${ }^{10}$ The literature on the risk effects of derivative use is large. Recent contributions include Instefjord (2005), Duffee and Zhou (2001), and Sinkey and Carter (2000).
} 


\section{Table 5}

\section{Trends at Failed Banks, Before and After 1995}

\begin{tabular}{|c|c|c|c|c|c|c|c|}
\hline \multirow[b]{2}{*}{ Variable } & \multirow[b]{2}{*}{$\begin{array}{l}\text { Quarters prior } \\
\text { to failure }\end{array}$} & \multicolumn{3}{|c|}{ Comparison of ratios at failed banks } & \multicolumn{3}{|c|}{$\begin{array}{l}\text { Comparison of } \\
\text { ratios at failed banks less peer values }\end{array}$} \\
\hline & & $\begin{array}{c}1995-2003 \\
(\%)\end{array}$ & $\begin{array}{c}\text { 1984-94 } \\
(\%)\end{array}$ & $\begin{array}{c}\text { Difference } \\
\text { of means (\%) } \\
\text { (t-statistic) }\end{array}$ & $\begin{array}{l}1995-2003 \\
(\%)\end{array}$ & $\begin{array}{c}\text { 1984-94 } \\
(\%)\end{array}$ & $\begin{array}{c}\text { Difference } \\
\text { of means (\%) } \\
\text { (t-statistic) }\end{array}$ \\
\hline \multirow[t]{2}{*}{ Jumbo CDs } & 1 & 14.70 & 18.80 & $-4.10 * *(-2.06)$ & 4.10 & 9.30 & $-5.2^{* * *}(-2.65)$ \\
\hline & 6 & 13.40 & 21.30 & $-7.90 * * *(-5.04)$ & 3.60 & 12.10 & $-8.5^{* * *}(-5.46)$ \\
\hline \multirow{2}{*}{$\begin{array}{l}\text { Federal funds } \\
\text { purchased }\end{array}$} & 1 & 0.37 & 0.99 & $-0.62 * * *(-3.30)$ & -1.15 & -0.20 & $-0.95^{* * *}(-5.07)$ \\
\hline & 6 & 0.77 & 1.29 & $-0.52(-1.64)$ & -0.69 & 0.17 & $-0.86 * * *(-2.72)$ \\
\hline \multirow[t]{2}{*}{ Demand deposits } & 1 & 12.70 & 14.90 & $-2.20(-1.23)$ & 0.70 & -4.80 & $5.5^{* * *}(-3.12)$ \\
\hline & 6 & 11.70 & 15.20 & $-3.5^{* *}(-1.99)$ & -0.40 & -6.30 & $5.8^{* * *}(-3.29)$ \\
\hline \multirow{2}{*}{$\begin{array}{l}\text { Loan-loss } \\
\text { reserves/loans }\end{array}$} & 1 & 4.04 & 3.14 & $0.90 * *(-2.15)$ & 2.51 & 1.90 & $0.61(-1.46)$ \\
\hline & 6 & 2.63 & 1.87 & $0.76^{* * *}(-3.7)$ & 1.06 & 0.67 & $0.38^{*}(-1.86)$ \\
\hline \multirow[t]{2}{*}{ Cash \& due } & 1 & 7.11 & 8.20 & $-1.08(-1.28)$ & 1.81 & -0.45 & $2.26^{* * *}(-2.67)$ \\
\hline & 6 & 6.14 & 9.03 & $-2.89 * * *(-3.7)$ & 0.85 & 0.17 & $0.68(-0.87)$ \\
\hline \multirow{2}{*}{$\begin{array}{l}\text { Commercial real } \\
\text { estate loans }\end{array}$} & 1 & 15.80 & 11.60 & $4.1^{* *}(-2.16)$ & -0.10 & 3.10 & $-3.3^{*}(-1.70)$ \\
\hline & 6 & 15.80 & 11.60 & $4.2^{* *}(-2.36)$ & 1.10 & 3.50 & $-2.50(-1.40)$ \\
\hline \multirow[t]{2}{*}{ Fee income } & 1 & 2.57 & 1.11 & $1.46^{* *}(-2.44)$ & 1.58 & 0.34 & $1.24 * *(-2.07)$ \\
\hline & 6 & 2.87 & 1.00 & $1.86(-1.59)$ & 1.91 & 0.29 & $1.62(-1.38)$ \\
\hline \multirow[t]{2}{*}{ OREO } & 1 & 1.70 & 3.48 & $-1.78^{* * *}(-3.78)$ & 1.54 & 3.11 & $-1.57^{* * *}(-3.33)$ \\
\hline & 6 & 1.49 & 1.70 & $-0.22(-0.55)$ & 1.30 & 1.40 & $-0.10(-0.25)$ \\
\hline \multirow[t]{2}{*}{ Total assets } & 1 & $\$ 133 M$ & $\$ 161 M$ & $-28 \mathrm{M}(-0.57)$ & $-\$ 88 M$ & $\$ 47 \mathrm{M}$ & $-\$ 135 \mathrm{M}^{* * *}(-2.72)$ \\
\hline & 6 & $\$ 137 \mathrm{M}$ & $\$ 192 M$ & $-\$ 55 \mathrm{M}(-0.88)$ & $-\$ 51 \mathrm{M}$ & $\$ 88 \mathrm{M}$ & $-\$ 139 \mathrm{M}^{* *}(-2.23)$ \\
\hline
\end{tabular}

NOTE: This table shows differences in means for selected risk variables between failing banks in the period 1995-2003 compared with those in 1984-94. Both the differences in levels and the differences in levels less peer values for the corresponding periods are given, at both 1 - and 6-quarter horizons. ${ }^{* * *}$, and ${ }^{* * *}$ indicate statistical significance at the 10,5 , and 1 percent levels, respectively. All of the nine variables reported here have exhibited significant changes since 1995 (by at least one of these difference-of-means tests) in their patterns as failure approaches.

for banks that move into them too hastily. With the increasing intensity of competition, many institutions have likely been tempted to do exactly that. The net effect on banks' risk positions is an empirical question.

\section{Evidence of Changes in the Nature of Bank Distress}

Although none of the institutional changes mentioned above necessarily implies any fundamental change in the process through which banks deteriorate, together they constitute a prima facie case that, at the very least, the previous results should be reaffirmed. Simple empirical analysis indicates that some of the above changes may indeed have had an impact on the typical pattern of bank distress. Figure 1 plots nine key ratio averages for failing banks in the 12 quarters leading to failure between 1984 and 1994 and between 1995 and 2003 against the contemporaneous averages for banks that did not fail. ${ }^{11}$ Of course, the number of failures in the earlier period was much larger-1,371 compared with 44-yet the patterns that emerge suggest that many characteristics of banks in the quarters before failure may have changed between the two time periods. Table 5, which reports difference-of-means tests

11 The December 1994 cutoff was chosen to exclude the failures of the early-1990s banking crisis from the more recent sample. Other break dates around the same time yield similar results. 


\section{Figure 1}

\section{Trends at Failed Banks, Before and After 1995}
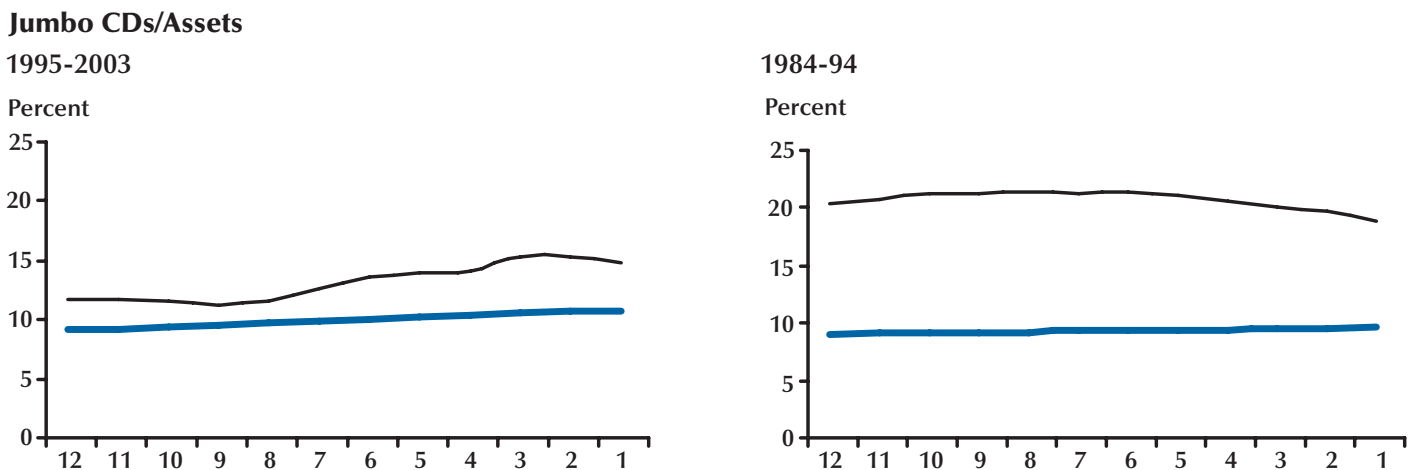

Federal Funds Purchased/Assets

1995-2003

Percent

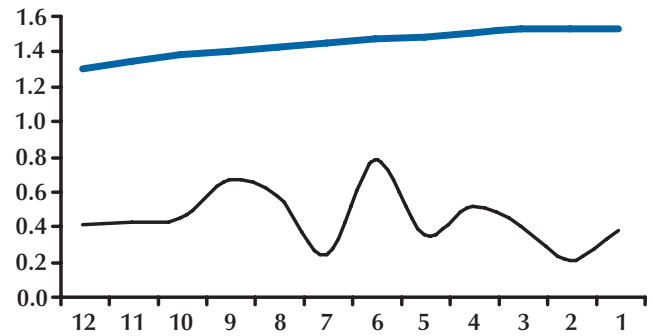

\section{Demand Deposits/Assets}

1995-2003

Percent

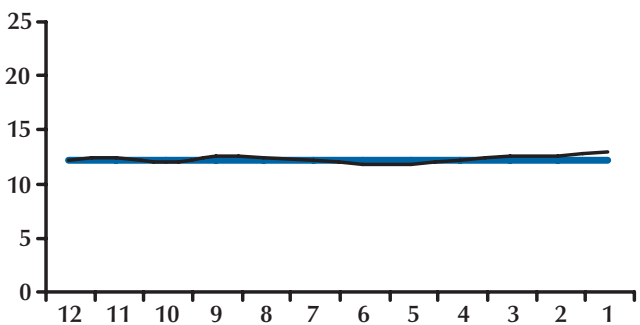

1984-94

Percent

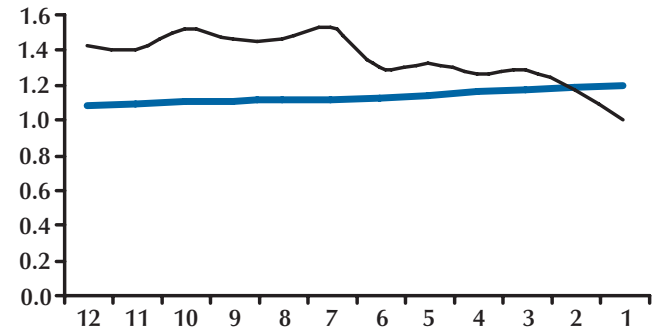

1984-94

Percent

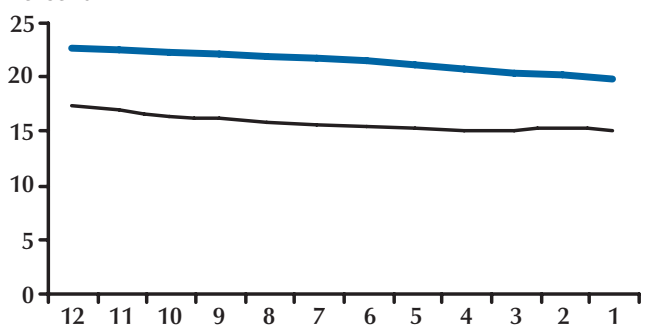

NOTE: This figure presents the information in Table 5 in graphical form. In each case, the thin black line indicates the path of a failing bank as the failure date approaches and the thick blue line indicates the average values for non-failing banks. Values on the horizontal axis indicate the number of quarters prior to failure. For every variable reported here, there is an obvious change in the pattern between the two periods. 


\section{Figure 1, cont'd}

\section{Trends at Failed Banks, Before and After 1995}
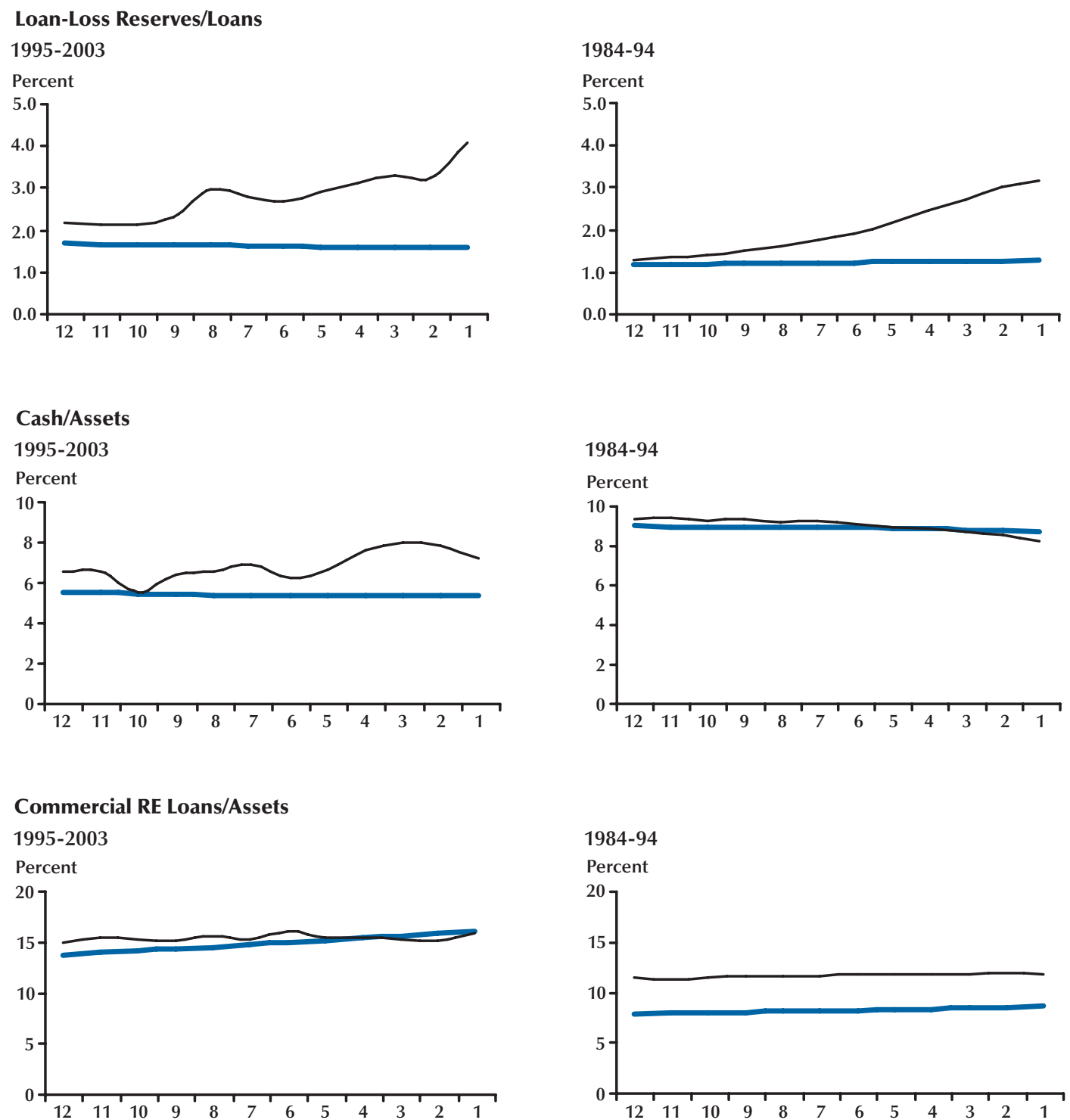

for the same series, shows that, despite the low number of failure observations in the second period, many of these changes are statistically significant. (The table reports the tests for one and six quarters prior to failure. The choice of the six-quarter horizon reflects the average time between bank exams.)

Failing banks in the 1995-2003 period had lower relative levels of liquidity risk than banks in the 1984-94 period. Specifically, between 1995 and 2003, failing banks relied substantially less on jumbo CDs and the purchase of federal funds, both in absolute terms and relative to safe banks. Although the ratio of demand deposits to total assets was lower for all banks in the later period, failing banks between 1995 and 2003 had ratios nearly identical to those at non-failing banks. In contrast, failing banks on average had significantly 


\section{Figure 1, cont'd}

\section{Trends at Failed Banks, Before and After 1995}

\section{OREO/Assets}

1995-2003

Percent

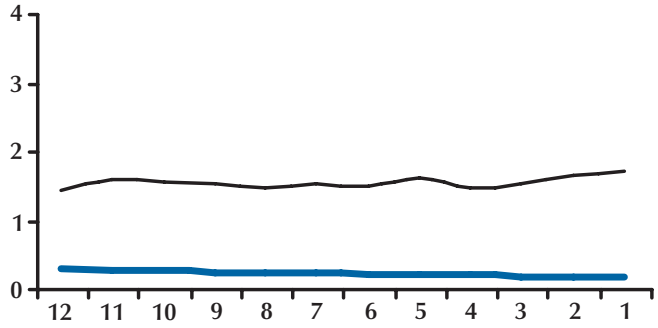

Fee Income/Assets

1995-2003

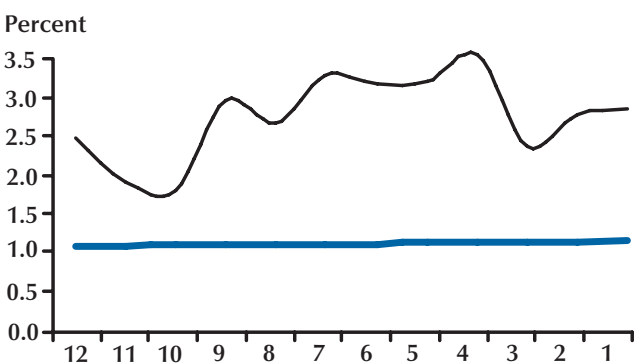

\section{Total Assets}

1995-2003

$\$$ Thousands

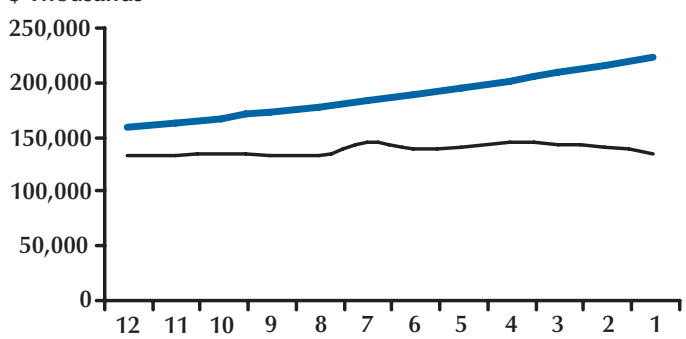

1984-94

Percent

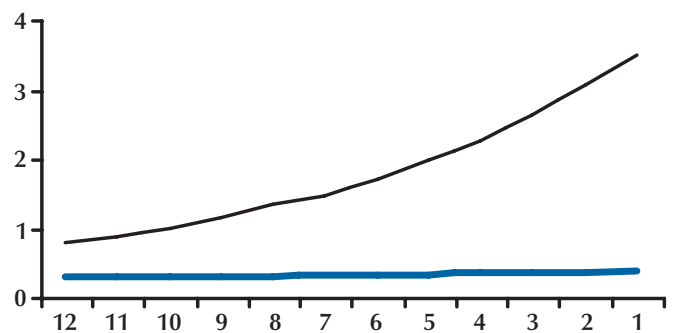

1984-94

Percent

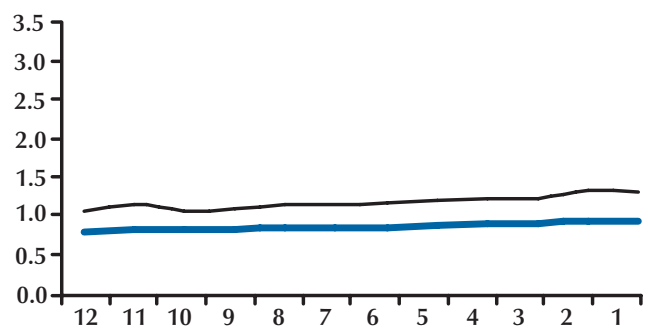

fewer demand deposits as a percentage of assets than non-failing banks in the 1984-94 period. Finally, the cash-to-assets ratio increased at failing banks in the quarters leading up to failure in the 1995-2003 period, whereas that ratio displayed little pre-failure trend in the earlier period. These interperiod differences in liquidity risk could reflect the increased depositor discipline imposed
1984-94

\$ Thousands

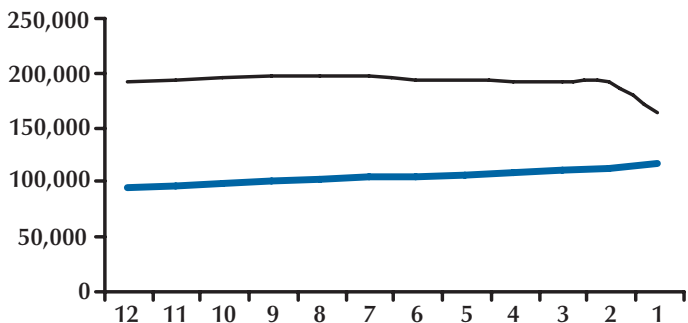

by the legislative changes of the 1990s, as risky banks in the 1995-2003 period may have had a more difficult time attracting uninsured funds.

Credit-risk ratios also reflect significant differences between the two periods. Commercial real estate lending was significantly higher (about 4 percentage points, scaled by assets) at failing banks relative to non-failing banks in the earlier 
period. In the later period the ratio was about the same at both failing and non-failing banks. Other real estate owned (OREO) as a percent of assets, previously one of the best predictors of failure, did not change substantially in the 1995-2003 period during the quarters leading up to failure. Although this ratio continues to be somewhat higher at failing banks relative to non-failing banks, the gap has shrunk, and the upward trend has nearly vanished. The loan loss reserves-to-total loans ratio was higher for failure banks in the later period than in the earlier period, although the ratio increased prior to failure in both time periods. The diminished importance of credit-risk ratios could reflect the improved risk-management processes at banks facilitated by the deepening of financial markets. Indeed, Schuermann (2004) argues that most banks came through the 2001 recession in excellent shape in part because of more effective risk management. Advances in credit scoring allowed banks to better risk-price their syndicated, retail, and small-business loans.

Two other ratios demonstrate the increased importance of diversification and nontraditional lines of business in recent years. Fee income as a percentage of assets, which was previously about the same at safe and failing banks, is now substantially higher for failing banks. Finally, failing banks were larger on average than non-failing banks in the earlier period but smaller in the later period, potentially reflecting the diversification benefits that banks receive from expanding in size and product offerings.

Despite the differences, we should be cautious about drawing strong conclusions from these graphs. The 1995-2003 sample contains only 44 bank-failure observations, so that, although most of our statistical tests yield statistically significant differences, the sample may not be entirely representative. In addition, some series that we have not emphasized have remained fairly constant. For example, failing banks continue to hold fewer mortgages and securities, and the pattern of capital deterioration has changed little. However, the fact remains that fundamental shifts in the banking environment make it possible that the path to bank distress has changed, and the recent data that are available are at least consistent with this possibility. Moreover, the shifts in the data-in variables associated with liquidity, credit, and operational risk-line up well with the types of institutional changes we know occurred during this period.

Because much of the academic research and most of the prevailing early-warning systems are based on data from the 1984-94 period, the above comparison gives us cause for concern. Indeed, these models tend to emphasize the variables that our evidence indicates have been most affected by the recent institutional changes. For example, eight of the eleven variables in SEER and 10 of the 12 variables in SCOR reflect either asset quality or liquidity. Recognition of the recent fundamental shifts in the nature of banking has motivated supervisors to consider new approaches to off-site monitoring.

\section{NEW DIRECTIONS IN BANK-DISTRESS MODELS}

In this section we describe some recent attempts by supervisory economists to build bank-distress models that (i) are less vulnerable than traditional models to the changing banking environment and (ii) are designed to assess risks that current models potentially overlook. We group the new models into two types: forward-looking models and risk-focused models. Forward-looking early-warning models may prove more robust to the changing bank environment because they rely on theory rather than past financial ratios to detect the circumstances that can lead banks to increase risk-taking. Risk-focused models reflect the shift to risk-focused supervision as explained in the Board of Governor's Supervision and Regulation Letter 97-25 titled "Risk-Focused Framework for the Supervision of Community Banks." The document, dated October 1, 1997, states the following:

The objective of a risk-focused examination is to effectively evaluate the safety and soundness of the bank...focusing resources on the bank's highest risks. The exercise of examiner judgment to determine the scope of the examination during the planning process is crucial to the implementation of the risk-focused supervision framework, which provides obvious benefits 


\section{King, Nuxoll, Yeager}

such as higher quality examinations, increased efficiency, and reduced on-site examiner time... [E]ach Reserve Bank maintains various surveillance reports that identify outliers when a bank is compared to its peer group. The review of this information assists examiners in identifying both the strengths and vulnerabilities of the bank and provides a foundation from which to determine the examination activities to be conducted.

Rather than identifying banks with high levels of overall risk, risk-focused monitoring devices attempt to assess the particular risks of banking organizations, allowing examiners to allocate resources to upcoming exams more efficiently. Risk-focused models have the added advantage that they scrutinize risks that traditional models may overlook because those risks were not systematically important in historical episodes of bank distress. We emphasize, however, that the new models should be viewed as complements to rather than substitutes for the more comprehensive and time-tested systems.

\section{Forward-Looking Models}

Forward-looking models tend to focus on asset growth and liquidity as key risk indicators. Adverse selection and moral hazard incentives provide complementary stories for why banks pursuing rapid asset-growth strategies may be ramping up risk.

The adverse selection story views banks as having well-established relationships with a core set of customers. On the liability side of the balance sheet, these customers provide stable low-cost funding, while on the asset side the bank has information about the creditworthiness of these customers that generally is not available to other lenders. Banks that pursue a rapid growth strategy must move into new markets or offer new products, finding both a new set of borrowers and the funds to finance the growth. Although growth is not a problem per se, the bank will suffer from adverse selection if its pool of prospective new borrowers is composed disproportionately of those who have been rejected by other banks. The question is whether the bank has sufficient expertise and devotes sufficient resources to address the credit problems inherent in rapid growth. These problems are not observable immediately because it takes time for loans to become delinquent.

The moral hazard story views deposit insurance and other sources of collateralized funding as vehicles for bank risk-taking. Banks keep the profits if the risks pay off, but leave the losses to the FDIC in the event of failure. Banks with relatively high capital ratios have incentives to manage their banks prudently because the owners of the bank have their own funds at stake. If capital ratios begin to slip, however, those incentives may erode (Keeley, 1990). When bank performance begins to deteriorate for whatever reason, managers and owners increasingly face the prospect of losing their wealth and jobs should regulators close the bank. Rather than watch the bank fail, management might prefer to gamble for resurrection by booking high-risk loans funded with insured or collateralized funding. Indeed, this type of behavior is often blamed, in part, for the magnitude of the 1980s' thrift crisis (White, 1991).

Banks traditionally have tried to avoid market discipline by relying on core deposits, and some evidence suggests that riskier banks shift to core funding for exactly this reason. ${ }^{12}$ Managers adopting this strategy, however, run up against two constraints. First, banks that deliberately try to sidestep market discipline with FDIC-insured deposits may invite greater regulatory scrutiny. Second, the limited supply of core funding imposes a natural ceiling on asset growth. Since the early 1990s, competition for insured deposits has intensified. Faced with less insured funding and greater demand for bank assets, managers have sought new funding sources. Banks that want to grow quickly but are unwilling to pay the risk premia demanded by uninsured liability holders may turn to noncore, non-risk-priced (NCNRP) sources of funding such as insured brokered deposits and FHLB advances. Brokered deposits funded much of the risky growth at thrifts during the 1980s. FHLB advances, which were historically available only to thrifts but became available to commercial banks in 1989, have many of

\footnotetext{
${ }^{12}$ Billet, Garfinkle, and O’Neal (1998).
} 


\section{Figure 2}

\section{Noncore, Non-Risk-Priced Funding at U.S. Banks}

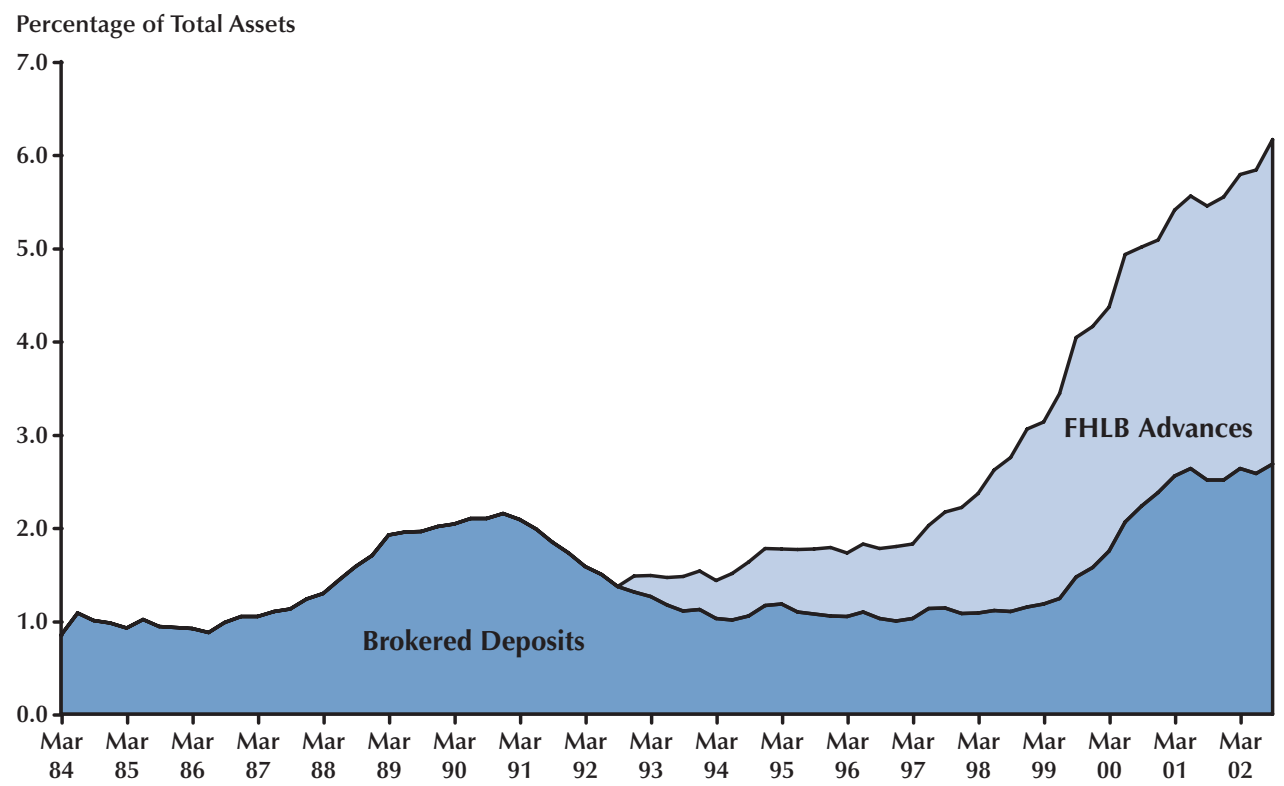

the same properties as brokered deposits. ${ }^{13}$ Both types of funding are easily accessible in large quantities, and neither is priced according to the failure risk of the borrower. Brokered deposits are insured by the FDIC, while FHLB advances are fully collateralized. The lenders, therefore, have little incentive to monitor a borrowing bank's condition.

As Figure 2 illustrates, bank reliance on brokered deposits and FHLB advances is at an historically high level, both in absolute terms and as a percentage of total bank assets. Advances in particular have grown from essentially 0 to 3.5 percent of banks' balance sheets since the early 1990s. Furthermore, rapid loan growth has accompanied the growth in noncore funding at many institutions. Between 1994 and 2004, bank lending increased 39 percent faster than total national income. Although aggregate capital levels and

\footnotetext{
${ }^{13}$ Stojanovic, Vaughan, Yeager (2001) provide further discussion of why the FHLB might create incentives for abnormal risk-taking and evidence in support of this hypothesis. Wang and Sauerhaft (1989) show that thrift reliance on FHLB advances and brokered deposits were associated with worse supervisory ratings in the 1980s.
}

overall bank condition remained relatively sound over this period, the rapid growth could be an indication of imprudent lending. The FDIC and the Federal Reserve Bank of St. Louis have independently developed alternative early-warning models called the Growth Monitoring System (GMS) and the Liquidity and Asset Growth Screen (LAGS), respectively, to address the adverse selection and moral hazard concerns. We briefly describe each in turn.

Growth Monitoring System. The FDIC has used the GMS as part of its off-site review process since the mid-1980s. The original model was an "expert system" in that its parameter values were assigned based on professional judgment, rather than statistical analysis. Weights were assigned to a number of growth-related variables in an attempt to identify those institutions most in danger of a rating downgrade. In the late 1990s, the FDIC developed a new version of this model using statistical techniques. This newer version of GMS, implemented in 2000, uses a logit model of downgrades, much like more traditional models, estimating which institutions that are 
currently rated satisfactory are most likely to be classified as problem banks at the end of three years. Rather than using credit-quality measures as independent variables, GMS includes forwardlooking variables that can be precursors of problems that have yet to become manifest. The key variables in the model are indicated in Table $3 .{ }^{14}$ Two variables have the most effect on the results: loan growth and noncore funding. Although the coefficient magnitudes vary somewhat over time, they are both statistically and economically significant. More rapid loan growth and heavy dependence on noncore funding generally lead to higher estimated default probabilities.

Back-testing of GMS shows that the model has significant forecasting power. ${ }^{15}$ Between 1996 and 2000, approximately 30 percent of the banks with GMS rankings at or above the 98th percentile received a rating of 3 or worse over the next five years. ${ }^{16}$ Among the banks with rankings at the 79th percentile or lower, just 8 percent were downgraded, so banks in the top two percentiles were approximately two and a half times more likely to receive a rating of 3 or worse.

The performance of GMS is even better when flagging more severe problems. Banks with GMS rankings at or above the 98th percentile were downgraded to a CAMELS 4 or 5 or failed 9.5 percent of the time; in contrast, banks with GMS ratings in the lower 79th percentile were downgraded to a rating of 4 or 5 or failed only 1.3 percent of the time. Finally, banks with GMS rankings at or above the 98th percentile were over eight times more likely to fail ( 0.76 percent) than those banks with rankings in the 79th percentile or

\footnotetext{
${ }^{14}$ Noncore funding, loans to total assets, and assets per employee are adjusted for size peers. The growth variables and the change in loan mix are not adjusted because there is no evidence that the size peers differ. All growth rates are measured year over year to avoid problems of seasonal adjustment. The growth rates of loans and assets are adjusted for mergers, but the growth rates in noncore funding and equity are not. This adjustment means that the model ignores acquisitions unless the acquisitions have eroded equity or made the bank more dependent on noncore funding.

15 The GMS system has also had particular success identifying recent failures due to fraud, although the exact reasons for this success require further investigation.

${ }^{16}$ Of course, the full five years has not passed for ratings assigned in the year 2000. The results are for those banks that survived five years or that filed a September 2003 call report.
}

lower (0.09 percent). It should be noted that while the GMS model has notable success in identifying risky institutions, many banks with high GMS rankings are never downgraded. In other words, the type-II error rate is high.

Liquidity and Asset Growth Screen. Like GMS, LAGS attempts to flag banks that use particular funding vehicles to fuel rapid asset growth. The central idea is that a bank that experiences a combination of falling capital ratios, rapid asset growth, and a surge in noncore, non-risk-priced funding exhibits the classic characteristics of moral hazard.

The LAGS model consists of ten separate panel vector autoregressions (VARs), identical in their variables but estimated on banks of different inflation-adjusted asset classes. The four dependent variables in the VARs are the quarterly growth rate of risk-weighted assets; the ratio of brokered deposits and FHLB advances to total assets; the CAMELS composite score; and the ratio of equity to total assets. ${ }^{17}$ The equations are estimated on rolling samples of quarterly data, updated every three months to include the most recent figures available. The key variable in the model is the CAMELS score. Banks that have higher forecasted CAMELS ratings over a three-year horizon are interpreted as being in greater danger of moralhazard-induced risk.

The charts in Figure 3 show how LAGS works for a hypothetical bank as of June 2004. In each of the four panels, the data to the left of the vertical black lines represent the bank's behavior over the previous two years. To the right of the black lines, the graphs show the LAGS forecasts. LAGS predicts that the sample bank's CAMELS score will rise from its present level of 1 to 1.78 over the next three years. LAGS ranks banking institutions by the predicted rise in total risk.

A closer look at the sample bank's recent history gives us an idea of why the model predicts

\footnotetext{
${ }^{17}$ Eight quarterly lags of each of these four variables are included as regressors in each of the four equations. The equations also include intercept terms. In total, then, LAGS consists of 40 linear regression equations each containing 36 variables. Banks are excluded from the sample if they are less than eight quarters old or have merged with another institution within the previous eight quarters. As of June 30, 2004, the dataset included approximately 175,000 observations.
} 


\section{Figure 3}

\section{LAGS Forecasts for an Anonymous Bank as of June 2004}
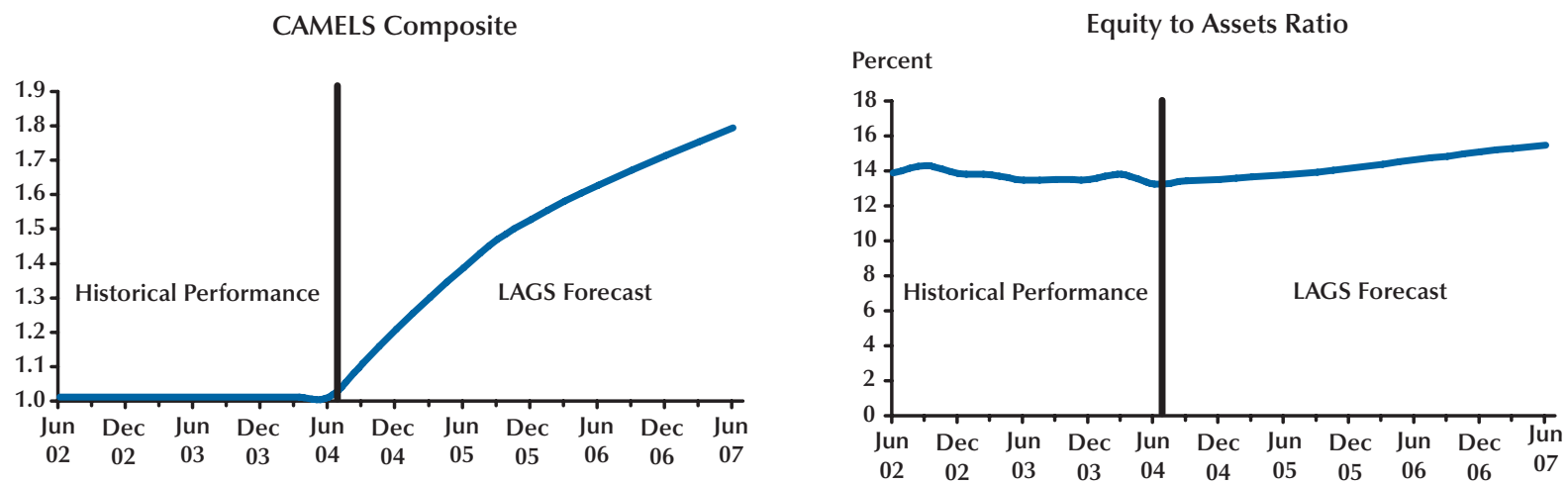

Percent of Assets

FHLB Advances and Brokered Deposits
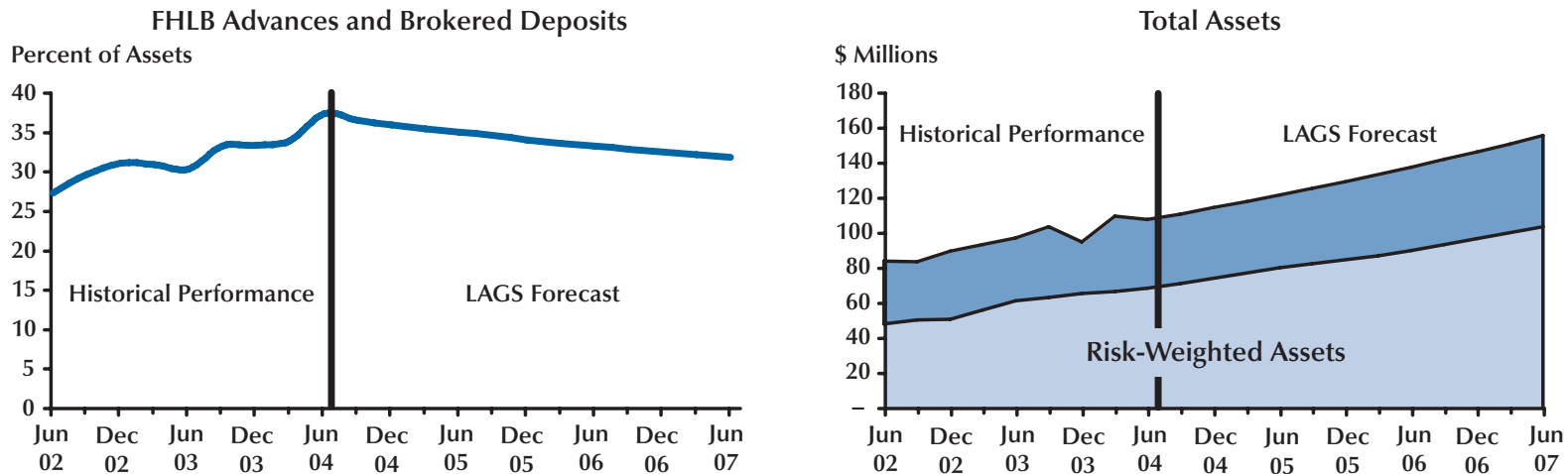

such a dramatic rise in risk. The bank grew rapidly between June 2002 and June 2004, increasing its assets by half and ratcheting up its risk-weighted asset ratio. The bank funded a substantial portion of this growth with FHLB advances and brokered deposits. As of June 2004, these liabilities supported over 35 percent of the bank's total assets, a ratio that rose more than 10 percentage points during the previous two years. Meanwhile, capital declined by about 100 basis points. The bank, therefore, displays key moral hazard characteristics.

Given the narrow focus of the LAGS model, we would not expect its performance to be as impressive as that of a more comprehensive model such as SEER, yet LAGS does display significant discriminatory ability. Between March 1998 and June 2001, 21.7 percent of banks with a CAMELS rating of 2 and a LAGS score at the 90th percentile or above were downgraded to a CAMELS score of 3,4 , or 5 or failed within the following three years. In addition, 47.1 percent of the 2-rated banks with a LAGS score at the 99th percentile or above were downgraded or failed within three years. By contrast, only 12.7 percent of banks below the 90th percentile were subsequently downgraded or failed. ${ }^{18}$

\section{Risk-Focused Models}

In addition to becoming more forward-looking, bank-distress models are also evolving to accommodate the risk-focused framework. Several off-site-monitoring devices have already been

${ }^{18}$ As noted, the LAGS coefficients are reestimated every quarter. The numbers reported in this paragraph reflect the estimates actually used in each quarter (rather than, say, the most recent set). In other words, they reflect out-of-sample forecasting ability. 
developed by the FDIC and the Federal Reserve, and more are in development. We describe two of these models here.

Real Estate Stress Test. Real estate crises have been perennial causes of bank failures. ${ }^{19}$ In 2000 , the FDIC implemented a Real Estate Stress Test (REST) that attempts to identify those banks and thrifts that are most vulnerable to problems in real estate markets. ${ }^{20}$

The REST model incorporates the experience of the New England real estate crisis of the early 1990s. Conceptually, the model subjects banks to the same stress as that crisis and forecasts the resulting CAMELS ratings. REST was developed by regressing performance data for New England banks in December 1990 on performance and portfolio data for the same banks in December 1987. These regressions identify the factors that were observable in 1987 that later were associated with safety and soundness concerns. A concentration in construction and development loans is the primary risk factor, but there are a host of secondary factors, such as concentrations in commercial mortgages, commercial and industrial loans, mortgages on multifamily housing, reliance on noncore funding, and rapid growth. These regressions are used to forecast measures of bank performance which are then translated to CAMELS ratings using the SCOR model. The result is a REST rating that ranges from 1 to 5 . The output from the model is distributed to FDIC examiners as well as examiners from other federal and state banking agencies. The model has been validated using data from other real estate downturns; it can identify banks that are vulnerable from real estate exposure three to seven years in advance.

Because of the long horizon, banks with poor REST ratings are not an immediate concern. More importantly, the model does not consider the underwriting standards and other aspects of risk management that the bank uses to control its exposure to real estate downturns. Consequently, examiners use the output from the REST model for examination planning. The model produces a set of "weights" indicating which variables are

\footnotetext{
${ }^{19}$ See Herring and Wachter (1999).

${ }^{20}$ See Collier et al. (2003b).
}

the most responsible for the poor rating, giving examiners a sense of the aspects of a bank's operations that deserve the most attention.

Interest Rate Risk. The savings and loan crisis of the 1980s focused increased attention in the banking industry on interest rate risk. Economists at the Board of Governors responded by developing a duration-based measure of interest rate risk that could be used for surveillance and risk-scoping purposes. ${ }^{21}$ The model, titled the Economic Value Model (EVM), was launched in the first quarter of 1998 by producing a confidential quarterly surveillance report (called the Focus report) for each commercial bank.

The EVM aggregates balance sheet items into various buckets based upon maturity and optionality. The model then uses the duration from a proxy financial instrument for each bucket to calculate the "risk weight," or the change in economic value of those items that would result from a 200-basis-point instantaneous rise in rates. For example, the EVM places all residential mortgages that reprice or mature within 5 to 15 years in the same bucket. If the risk weight for the 5- to 15-year mortgages were 7.0, the value of the 5- to 15 -year mortgages would be estimated to decline by 7.0 percent following an immediate 200-basis-point rate hike. The change in economic value is repeated for each balance sheet bucket. The predicted change in economic value of the bank's equity, then, is the difference between the predicted change in assets and the predicted change in liabilities.

Recent research by Sierra and Yeager (2004) shows that the EVM effectively ranks banks by their exposure to rising interest rates. That is, banks that the model predicts to be the most vulnerable to rising interest rates suffer the largest declines in income and equity following an interest rate hike. These banks also show the largest gains in income and equity following interest rate declines. Bank supervisors can use the model's output to rank banks by interest rate risk. If a bank is found to be an outlier, the examiner in charge will emphasize that risk in the next exam.

\footnotetext{
${ }^{21}$ See Embersit and Houpt (1991) and Houpt and Wright (1996) for details.
} 


\section{CONCLUSION}

After their initial introduction in the 1970s, studies on the causes of bank distress made rapid progress, fueled by considerable academic interest. In recent years, this interest has waned outside the regulatory community, possibly reflecting a belief that the causes of bank distress are well understood. However, significant legislative, financial, and technological innovations may make it necessary to supplement the prevailing academic and regulatory models with a new generation of forward-looking and risk-focused monitoring systems.

Newer forward-looking models at the FDIC and the Federal Reserve include the Growth Monitoring System and the Liquidity and AssetGrowth Screen. Risk-focused models include the Real Estate Stress Test and the Economic Value Model. Additional monitoring devices such as those analyzing liquidity risk, operational risk, and counterparty risk seem promising lines of inquiry.

\section{REFERENCES}

Altman, Edward I. "Financial Ratios, Discriminant Analysis, and the Prediction of Corporate Bankruptcy." Journal of Finance, September 1968, 23(4), pp. 589-609.

Altman, Edward I. "Predicting Performance in the Savings and Loan Association Industry." Journal of Monetary Economics, October 1977, 3(4), pp. 443-66.

Barth, James; Brumbaugh, Dan Jr.; Sauerhaft, Daniel and Wang, George H.K. "Thrift Institution Failures: Estimating the Regulator's Closure Rule," in George Kaufman, ed., Research in Financial Services. Greenwich, CT: JAI Press, 1989, pp. 1-25.

Bennett, Rosalind L.; Vaughan, Mark D. and Yeager, Timothy J. "Should the FDIC Worry about the FHLB? The Impact of Federal Home Loan Bank Advances on the Bank Insurance Fund." Supervisory Policy Analysis Working Paper 2005-1, Federal Reserve Bank of St. Louis, July 2005.

Billet, Matthew T.; Garfinkle, Jon A. and O’Neal,
Edward S. "The Cost of Market vs. Regulatory Discipline in Banking." Journal of Financial Economics, 1998, 48(3), pp. 333-58.

Bovenzi, John F.; Marino, James A. and McFadden, Frank E. "Commercial Bank Failure Prediction Models.” Federal Reserve Bank of Atlanta Economic Review, November 1983, 68, pp. 14-26.

Claessens, Stijn; Glaessner, Thomas and Klingebiel, Daniela. "Electronic Finance: Reshaping the Financial Landscape around the World." Journal of Financial Services Research, August-October 2002, 22(1-2), pp. 29-61.

Cole, Rebel A. "When Are Thrift Institutions Closed? An Agency-Theoretic Model.” Journal of Financial Services Research, December 1993, 7(4), pp. 283-307.

Cole, Rebel A.; Cornyn, Barbara G. and Gunther, Jeffery W. "FIMS: A New Monitoring System for Banking Institutions.” Federal Reserve Bulletin, January 1995, 8(1), pp. 1-15.

Cole, Rebel A. and Gunther, Jeffery W. "Predicting Bank Failures: A Comparison of On- and Off-Site Monitoring Systems." Journal of Financial Services Research, April 1998, 13(2), pp. 103-17.

Collier, Charles; Forbush, Sean; Nuxoll, Daniel A. and O’Keefe, John. “The SCOR System of Off-Site Monitoring." FDIC Banking Review, Third Quarter 2003a, 15(3), pp. 17-32.

Collier, Charles; Forbush, Sean and Nuxoll, Daniel A. "The Vulnerability of Banks and Thrifts to a Real Estate Crises.” FDIC Banking Review, Fourth Quarter 2003b, 15(4), pp. 19-36.

Cornett, Marcia M.; Mehran, Hamid and Tehranian, Hassan. "The Impact of Risk-Based Premiums on FDIC-Insured Institutions." Journal of Financial Services Research, April 1998, 13(2), pp. 153-69.

Cox, D.R. "Regression Models and Life Tables." Journal of the Royal Statistical Society, 1972, Series B (34), pp. 187-220.

Craig, Ben R. and Thomson, James B. "Federal Home Loan Bank Lending to Community Banks: Are 
Targeted Subsidies Desirable?" Journal of Financial Services Research, February 2003, 23(1), pp. 5-28.

Demirgüç-Kunt, Asli. "Modeling Large CommercialBank Failures: A Simultaneous-Equations Analysis." Working Paper 8905, Federal Reserve Bank of Cleveland, March 1989.

Duffee, Gregory R. and Zhou, Chunsheng. "Credit Derivatives in Banking: Useful Tools for Managing Risk?" Journal of Monetary Economics, August 2001, 48(1), pp. 25-54.

Embersit, James A. and Haupt, James V. "A Method for Evaluating Interest Rate Risk in U.S. Commercial Banks." Federal Reserve Bulletin, August 1991, 77(8), pp. 625-37.

Flannery, Mark J. and Rangan, K. "Market Forces at Work in the Banking Industry: Evidence from the Capital Buildup of the 1990s.” Working paper, University of Florida-Gainesville, 2003.

Flannery, Mark J. and Sorescu, Sorin M. "Evidence of Bank Market Discipline in Subordinated Debenture Yields: 1983-1991.” Journal of Finance, September 1996, 51(4), pp. 1347-77.

Gilbert, R. Alton; Meyer, Andrew P. and Vaughan, Mark D. "The Role of Supervisory Screens and Econometric Models in Off-Site Surveillance." Federal Reserve Bank of St. Louis Review, November/December 1999, 81(6), pp. 2-27.

Gilbert, R. Alton; Meyer, Andrew P. and Vaughan, Mark D. "Could a CAMELS Downgrade Model Improve Off-Site Surveillance?” Federal Reserve Bank of St. Louis Review, January/February 2002, 84(1), pp. 47-63.

Goldberg, Lawrence G. and Hudgins, Sylvia C. "Depositor Discipline and Changing Strategies for Regulating Thrift Institutions." Journal of Financial Economics, February 2002, 63(2), pp. 263-74.

Hall, John R.; King, Thomas B.; Meyer, Andrew P. and Vaughan, Mark D. "Did FDICIA Enhance Market Discipline at Community Banks?” in George G. Kaufman, ed., Research in Financial Services: Private and Public Policy. Volume 14. Boston: Elsevier, 2002, pp. 63-94.
Hanweck, Gerald A. "Predicting Bank Failure." Board of Governors of the Federal Reserve System, Research Papers in Banking and Financial Economics, November 1977, 19.

Helwege, Jean. "Determinants of Savings and Loan Failures: Estimates of a Time-Varying Proportional Hazard Function." Journal of Financial Services Research, December 1996, 10(4), pp. 373-92.

Herring, Richard J. and Wachter, Susan M. "Real Estate Booms and Banking Busts-An International Perspective." Occasional Paper No. 58. Group of Thirty, 1999.

Hirtle, Beverly J. and Lopez, Jose A. "Supervisory Information and the Frequency of Bank Examinations," Federal Reserve Bank of New York Economic Policy Review, April 1999, 5(1), pp. 1-19.

Hooks, Linda M. "Bank Asset Risk: Evidence from Early-Warning Models." Contemporary Economic Policy, October 1995, 13(4), pp. 36-50.

Houpt, James V. and Wright, David M. "An Analysis of Commercial Bank Exposure to Interest Rate Risk." Federal Reserve Bulletin, February 1996, 82(2), pp. 115-28.

Instefjord, Norvald. "Risk and Hedging: Do Credit Derivatives Increase Bank Risk?", Journal of Banking and Finance, February 2005, 29(2), pp. 333-45.

Keeley, Michael C. "Deposit Insurance, Risk, and Market Power in Banking." American Economic Review, December 1990, 80(5), pp. 1183-200.

King, Thomas B. "Discipline and Liquidity in the Market for Federal Funds." Supervisory Policy Analysis Working Paper 2003-2, Federal Reserve Bank of St. Louis, October 2005.

Korobow, Leon; Stuhr, David P. and Martin, Daniel. "A Nationwide Test of Early Warning Research in Banking.” Federal Reserve Bank of New York Quarterly Review, Autumn 1977, 2(2), pp. 37-52.

Lane, William R.; Looney, Stephen W. and Wansley. James W. "An Application of the Cox Proportional Hazards Model to Bank Failure." Journal of Banking and Finance, December 1986, 10(4), pp. 511-31. 
Marino, James A. and Bennett, Rosalind L. "The Consequences of National Depositor Preference." FDIC Banking Review, October 1999, 12(2), pp. 19-38.

Martin, Daniel. "Early Warning of Bank Failure: A Logit Regression Approach.” Journal of Banking and Finance, November 1977, 1, pp. 249-76.

Meyer, Paul A. and Pifer, Howard W. "Prediction of Bank Failures." Journal of Finance, September 1970, pp. 853-68.

Meyer, Andrew P. and Yeager, Timothy J. "Are Small Rural Banks Vulnerable to Local Economic Downturns?" Federal Reserve Bank of St. Louis Review, March/April 2001, 83(2), pp. 25-38.

Neely, Michelle C. and Wheelock, David C. "Why Does Bank Performance Vary Across States?” Federal Reserve Bank of St. Louis Review, March/April 1997, 79(2), pp. 27-40.

Nuxoll, Daniel; O’Keefe, John and Samolyk, Katherin. "Do Local Economic Data Improve Off-Site Bank Warning Models?” FDIC Banking Review, 2003, 15(2), pp. 39-53.

Pantalone, Coleen C. and Platt, Marjorie B. "Predicting Commercial Bank Failure since Deregulation." Federal Reserve Bank of Boston New England Economic Review, July/August 1987, pp. 37-47.

Putnam, Barron H. "Early-Warning Systems and Financial Analysis in Bank Monitoring." Federal Reserve Bank of Atlanta Economic Review, November 1983, 68, pp. 6-14.

Rose, Peter S. and Scott, William L. "Risk in Commercial Banking: Evidence from Postwar Failures." Southern Economic Journal, July 1978, 45(1), pp. 90-106.

Schuermann, Til. "Why Were Banks Better Off in the 2001 Recession?" Federal Reserve Bank of New York Current Issues in Economics and Finance, January 2004, 10(1), pp. 1-7.

Sierra, Gregory E. and Yeager, Timothy J. "What Does the Federal Reserve's Economic Value Model Tell Us about Interest Rate Risk at U.S. Community Banks?" Federal Reserve Bank of St. Louis Review, November/December 2004, 86(6), pp. 45-60.
Sinkey, Joseph F. Jr. "A Multivariate Statistical Analysis of the Characteristics of Problem Banks." Journal of Finance, March 1975, 30(1), pp. 21-36.

Sinkey, Joseph F. Jr. “Identifying 'Problem’ Banks: How Do the Banking Authorities Measure a Bank's Risk Exposure?" Journal of Money, Credit, and Banking, May 1978, 10(2), pp. 184-93.

Sinkey, Joseph F. Jr. and Carter, David A. "Evidence on the Financial Characteristics of Banks That Do and Do Not Use Derivatives." Quarterly Review of Economics and Finance, Winter 2000, 40(4), pp. 431-49.

Stojanovic, Dusan; Vaughan, Mark D. and Yeager, Timothy J. "Do Federal Home Loan Bank Advances and Membership Lead to More Bank Risk?" in Federal Reserve Bank of Chicago, ed., The Financial Safety Net: Costs, Benefits, and Implications for Regulations-Proceedings of the 37th Annual Conference on Bank Structure and Competition, May 2001, pp. 165-96.

Stuhr, David P. and van Wicklen, Robert. "Rating the Financial Condition of Banks: A Statistical Approach to Aid Bank Supervision.” Federal Reserve Bank of New York Monthly Review, September 1974, pp. 233-8.

Thomson, James B. “Modeling the Bank Regulator's Closure Option: A Two-Step Logit Regression Approach." Journal of Financial Services Research, May 1992, 6(1), pp. 5-23.

Wang, George H.K. and Sauerhaft, Daniel.

"Examination Ratings and the Identification of Problem/Non-Problem Thrift Institutions." Journal of Financial Services Research, October 1989, 2(4), pp. 319-42.

West, Robert Craig. "A Factor-Analytic Approach to Bank Condition." Journal of Banking and Finance, June 1985, 9(2), pp. 253-66.

Whalen, Gary. "A Proportional Hazards Model of Bank Failure: An Examination of Its Usefulness as an Early Warning Tool." Federal Reserve Bank of Cleveland Economic Review, First Quarter 1991, pp. 20-31. 


\section{King, Nuxoll, Yeager}

Whalen, Gary and Thomson, James B. "Using Financial Data to Identify Changes in Bank Condition." Federal Reserve Bank of Cleveland Economic Review, Second Quarter 1988, pp. 17-26.

Wheelock, David C. and Wilson, Paul W. "Explaining Bank Failures: Deposit Insurance, Regulation, and Efficiency." Review of Economics and Statistics, 1995, 77(4), pp. 689-700.

Wheelock, David C. and Wilson, Paul W. "Why Do Banks Disappear? The Determinants of U.S. Bank Failures and Acquisitions." Review of Economics and Statistics, February 2000, 82(1), pp. 127-38.

Wheelock, David C. and Wilson, Paul W. "The Contribution of On-Site Examination Ratings to an Empirical Model of Bank Failures." Review of Accounting and Finance, 2005 (forthcoming).

White, Eugene N. The Comptroller and the Transformation of American Banking. Washington, DC: Office of the Comptroller of the Currency, 1992, pp. 1960-90.

White, Lawrence J. The S\&L Debacle: Public Policy Lessons for Bank and Thrift Regulation. New York: Oxford University Press, 1991.

Yeager, Timothy J. "The Demise of Community Banks? Local Economic Shocks Are Not to Blame." Journal of Banking and Finance, September 2004, 28(9), pp. 2135-53.

Yeager, Timothy J.; Yeager, Fred C. and Harshman, Ellen. "The Financial Services Modernization Act: Evolution or Revolution?" Federal Reserve Bank of St. Louis Working Paper No. 2004-05, 2005. 